0 The Influence of Perceived Ease of Use, Discount,.... .

Vol. 27, No. 2 August 2019

(C) Centre for Indonesian Accounting and Management Research Postgraduate Program, Brawijaya University 


\title{
THE INFLUENCE OF PERCEIVED EASE OF USE, DISCOUNT, AND PERCEIVED USEFULNESS ON INTENTION TO USE GRAB APLICATION AND IT'S IMPACT ON PURCHASE DECISION OF GRAB SERVICES
}

\author{
Nursakinah Ritonga ${ }^{1 *}$, Endang Siti Astuti ${ }^{2}$, Sunarti $^{3}$ \\ ${ }^{1}$ Magister Program of Business Administration, University of Brawijaya,, Malang \\ Indonesia \\ ${ }^{2}$ Department of Business Administration,Faculty of Administrative Science, Universitas \\ Brawijaya, \\ Malang Indonesia
}

\begin{abstract}
The purpose of this reseacrh is to explain and analyze the influence of Perceived Ease of Use, Discount, Perceived Usefulness on Intention to Use the Grab application and its impact on Grab service purchasing decisions. This study uses a quantitative approach using explanatory research. The population of this study is undergraduate students in business administration study programs for 2017 and 2018 Faculty of Administrative Sciences, Universitas Brawijaya, Malang. with a total of 734 people. To determine the sample of the population, researchers used the Yamane formula to obtain the number of respondents as many as 90 people. The sampling technique of this study is non probability sampling technique with the number of samples taken proportionally following the number of students in 2017 and 2018. The method of data collection used a questionnaire distributed to the respondent classes and calculated using a Likert scale.Data analysis methods consist of test instruments, research requirements testing and hypothesis testing with path ananlysis by SPSS. The results of this study indicate that the Perceived Ease of Use, Discount, Perceived Usefulness has a positive and significant effect on the Intention to use Grab application. In addition the variable Perceived Ease of Use, Discount, Intention to Use Grab application also has a positive and significant influence on purchasing decisions. While the Perceived Usefulness variable has not significant effect on Purchasing Decisions.
\end{abstract}


Keywords: Perceived Ease of Use, Discount, Perceived Usefulness, Intention to Use, Purchase Decision

\section{INTRODUCTIONS}

Intention to Use is one of the processes in purchasing of a product or service before making a decision to buy a product or service. In this study, purchase intention is a variable that connects TAM (Technology Acceptance Model) as the grand teory which consists of two variable, perceived ease of use and perceived usefulness. The midle range theory is marketing theory through discount variable. Intention on technology acceptance model discusses consumer intention to use Grab application while intention on marketing refers to consumer intention to do purchase decision.

Intention to use is driven by the desire of a consumer to buy a product on their needs. According to Kotler and Keller (2007) consumer buying intention is a behavior where consumers have the desire to buy or choose a product or service.

In this study, purchase intention is influenced by Perceived Ease of Use, Discount, and perceived usefulness. Perceived Ease of Use and Perceived Usefulness are the key factors in technology or application acceptance. Perceived Ease of use is also defined as the extent to which a person believes that using a technology will be less of effort and has a significant effect on Purchasing Decisions (Jogiyanto, 2007: 118). Whereas according to Jogiyanto (2008) Perceived Usefulness is the extent to which individuals believe using a technology will improve their work performance or activities. Research conducted by Johar et al (2011), Hsieh (2011) shows that there is a positive influence between TAM through Perceived Ease of Use and Perceived Usefulness on technology acceptance / use of technology.

Apart from the perceived ease of use and perceived usefulness, promotion can encourage consumer intention to buy a product or service. One type of effective promotion is discounts. Kotler and Keller (2007: 103) States that "the company will adjust its price list and provide discounted prices to consumers to encourage faster payments, purchases in the largest amount, and encourage purchase intentions out of season. Whereas according to Tjiptono (2008: 166) a discount is a price discount given by the seller to the buyer as an appreciation for certain activities from a pleasant purchase for the seller.

In terms of the intention to use the Grab application, there is a problem that the high intention to use Grab application is not necessarily followed by consumer purchasing 
decisions on Grab services. Purchasing decision according to Kotler and Armstrong (2012: 154) is buyers' decision about the choice of brands that consumers buy. Consumers who have downloaded the Grab application are still uncertain about ordering Grab services. Often there are conditions where the consumer stops the intention without being followed by the purchase decision. There are other factors such as Perceived Ease of Use, Discount, and Perceived Usefulness that can affect the purchase decision of Grab services.

Grab was founded by Anthony Tan and Hooi Ling Tan who are Malaysian citizens in 2012. Grab began expanding in Indonesia starting in June 2012 as a taxi booking application and since then has provided a variety of transportation options, courier services, and online shopping. The following are Grab services in Indonesia which consist of 8 types of services (Grab Indonesia, 2019) :

1. GrabTaxi

2. GrabCar

3. GrabBike

4. GrabExpress

5. GrabFood

6. Grab fresh

7. GrabCar (Beta)

8. GrabPulsa 


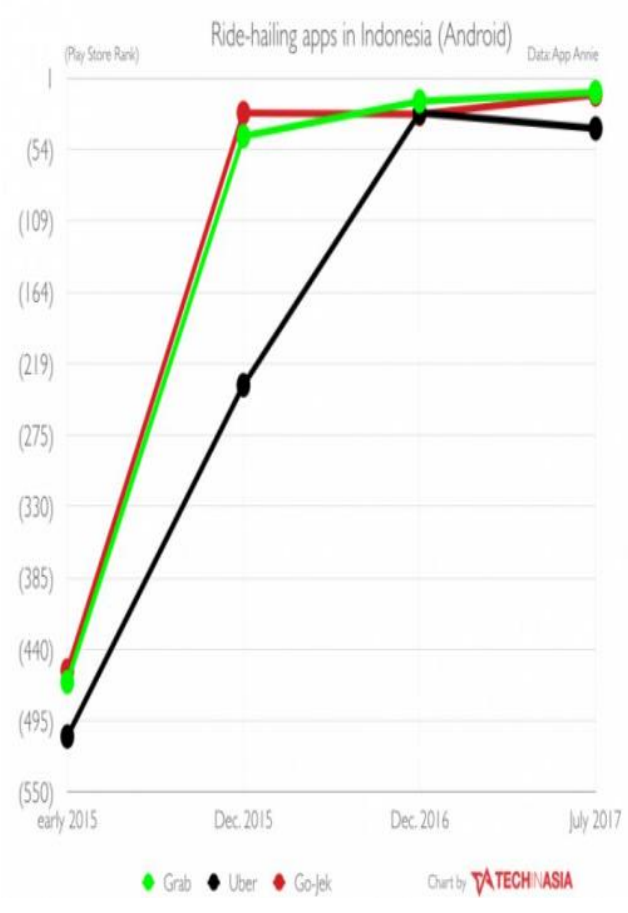

Figure 1. Grab Chart

\section{Source: TECHNASIA (2017)}

The graph above is published by TECHNASIA in 2017. The application rating is calculated not only based on the number of downloads, but also the number of uninstallations, ratings, and time of use. From the graph above, it can be seen that Grab is almost equal to the ranking of the Go-Jek application which first entered the market in Indonesia. From the graph, it can be seen that there is an increase in Grab rank in Indonesia from year to year.

Grab began operating in Malang City starting from 2016. After obtaining an operating permit from the government, online transportation including Grab made an agreement with conventional transportation. Some specific areas are not permitted to enter online transportation such as Arjosari terminals, train stations, shopping places. The area which includes crowded passengers is devoted to conventional transportation such as public transportation and base motorbikes. While for other regions such as Grab University, Grab is free to accept orders from consumers in accordance with the Grab application. 
The University is one of the potential market segments for Grab, especially students who are still active with busy lectures still.

From the background described, the purpose of this study is to explain and analyze the influence of the Perceived Ease of Use on customer intentions to use Grab application. To explain and analyze the influence of Discount on customer intentions to use Grab application. To explain and analyze the influence of Perceived Usefulness on customer intentions to use Grab application.

To explain and analyze the influence of Perceived Ease of Use, Discount, Perceived Usefulness through the Intention to Use Grab application to Purchase Decisions of Grab services. To explain and analyze the influence of the Perceived Ease of Use on Purchase Decision of Grab services. To explain and analyze the influence of Perceived Usefulness on Purchase Decision of Grab services. To explain and analyze the influence of Discount on the Purchase Decision of Grab services.

\section{RESEARCH METHODS}

This study uses a quantitative approach using explanatory research. The data analysis method used in this study is a research instrument test consisting of validity and reliability tests. Research feasibility test consisting of normality test and linearity test. Descriptive analysis and research hypothesis testing by used path analysis.

\section{Data Collection Methods}

The research data collection method uses questionnaires and literature studies. The population in this study is undergraduate students in business administration study programs for 2017 and 2018, Faculty of Administrative Sciences, Universitas Brawijaya, Malang.

To determine the sample size of the existing population, researchers used the Yamane formula and obtained the number of respondents as many as 90 respondents. The sampling technique used in this study was non probability sampling with the number of samples taken proportionally according to the number of students in 2017 and 2018.

Questionnaires were distributed by entering the respondent classes that had been determined, namely undergraduate students of 2017 in business administration study programs consisting of 11 classes and undergraduate students of 2018 consisting of 11 classes. But to avoid duplication of respondents, researchers only distributed 
questionnaires on Thursday 7 March 2019 for the 2017 class at 09.10 WIB as many as 4 classes. while the questionnaire distributed to 2018 class at $15.10 \mathrm{WIB}$ as many as 4 classes

\section{RESULTS AND DISCUSSIONS}

From the results of the respondents' description analysis it was concluded that the majority of respondents were female, aged 18 years and started using Grab services from 2017. Before deciding to buy Grab services, the majority of respondents sought information about Grab's services. The most commonly Grab services that used by respondents are GrabBike, GrabCar, and GrabFood. All respondents in this study have already received a Grab discount. The most commonly discount that used by responded is the Grab discount in the form of a promo code. From the results of the variables description analysis, the respondent's answer that the variables Perceived Ease of Use, Discount, Perceived Usefulness, Intention to Use the Application, and Purchase Decision is good or high.

The results of the validity test show that all statement items in this study have a number of $r$ counts greater than $r$ table 0.1745 . Likewise with the reliability test results which show that the reliability coefficient value is $>0.6$. thus it can be concluded that the questionnaire used in this study is valid and reliable.

The classic assumption test results in this study can be seen that based on the Kolmogorovosmirnov test the significance value is 0.200 which is greater than 0.1 so it can be concluded that the data is normally distributed. Furthermore, the linearity test it can be seen that the correlation value of the three independent variables on the 2 dependent variables all shows a significance value greater than 0.1 . Thus it can be concluded that the data in this study are linear.

The image below shows the results of path analysis using regression: 
PY2X1 $=0,269$

$(P=0.003)$

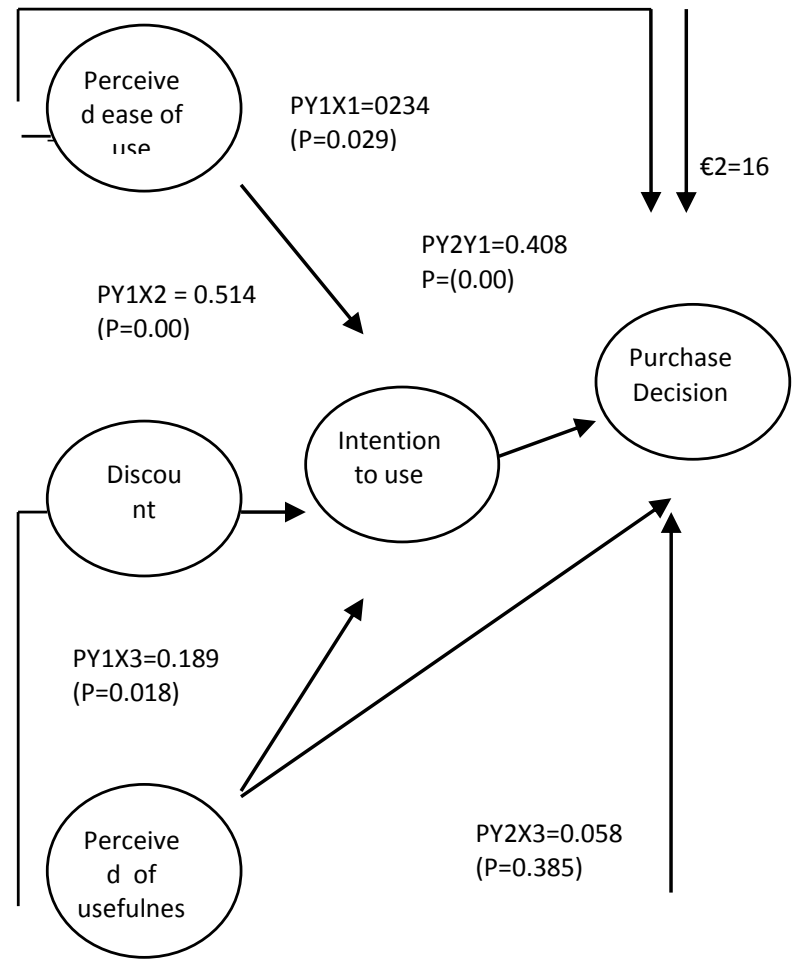

PY2X2 $=0.247$

$(P=0.016)$

Figure 2. research framework

From the results of variable analysis, perceived ease of use has a positive and significant influence on the intention to use the application at an error rate of $0.1(\alpha=10 \%)$. This can be seen from the path coefficient of 0.234 with a sig value of $0.029(0.029<0.10)$ so that the variable perceived ease of use (X1) has a significant effect on the intention to use the Grab application (Y1).

The results of the discount variable analysis have a positive and significant influence on the intention to use Grab application at an error rate of $0.1(\alpha=10 \%)$. This can be seen 
from the path coefficient of 0.514 with a sig value of $0,000(0,000<0,10)$ so that the discount variable (X2) has a significant effect on the intention to use Grab application (Y1)

From the results of the analysis of perceived usefulness variable have a positive and significant effect on the intention to use Grab application at an error rate of $0.1(\alpha=10 \%)$. This can be seen from the path coefficient of 0.189 with a sig value of $0.018(0.018<0.10)$ so that the perceived usefulness variable (X3) has a significant effect on the intention to use Grab application (Y1).

The contribution of the variables Perceived Ease of Use, Discount, Perceived Usefulness to the Intention to Use Grab Application can be seen from the value of Adjusted R Square which is equal to 0.763 . This means that $76.3 \%$ of the consumer's intention to use Grab application will be influenced by the independent variables, namely the Perceived Ease of Use, Discount, Perceived Usefulness. While the remaining $23.7 \%$ will be influenced by other variables not used in this study.

From the results of the analysis of the intention to use the application variable has a positive and significant influence on purchasing decisions at an error rate of $0.1(\alpha=$ $10 \%)$. This can be seen from the path coefficient of 0.408 with a sig value of $0,000(0,000$ $<0,10$ ) so that it can be seen that the intention to use Grab application variable (Y1) has a significant effect on purchasing decisions (Y2).

From the results of the analysis of perceived ease of use variable has a positive and significant influence on purchasing decisions at an error rate of $0.1(\alpha=10 \%)$. This can be seen from the path coefficient of 0.269 with a sig value of $0.003(0.003<0.10)$ so that the variable perceived ease of use (X1) has a significant effect on purchasing decisions (Y2).

From the results of the analysis of perceived usefulness variable has a positive but not significant effect on purchasing decisions at an error rate of $0.1(\alpha=10 \%)$. This can be seen from the path coefficient of 0.058 with the value of sig $0.385(0.385>0.10)$ so that the variable perceived ease of use (X1) has a positive but not significant effect on purchasing decisions (Y2).

From the results of the discount variable analysis has a positive and significant influence on purchasing decisions at an error rate of $0.1(\alpha=10 \%)$. This can be seen from the path coefficient of 0.247 with a sig value of $0.016(0.016<0.10)$ so that the discount variable (X2) has a significant effect on purchasing decisions (Y2). 
The contribution of Perceived Ease of Use (X1), Discount (X2), Perceived Usefulness (X3) variables, Intention to Use the Grab Application (Y1) to Purchase Decisions (Y2) can be seen from the Adjusted R Square value of 0.84 . This means that $84 \%$ of the Purchase Decision variable will be influenced by the independent variables, namely the Perceived Ease of Use (X1), Discount (X2), Perceived Usefulness (X3), Intention to Use the Grab Application (Y1). While the remaining 16\% is influenced by other variables not used in this study.

\begin{tabular}{|l|l|}
\hline Direct Influence \\
\hline Inter-Variable Influence & $\begin{array}{l}\text { Path } \\
\text { Coefficient }\end{array}$ \\
\hline $\begin{array}{l}\text { Perceived Ease of Use (X1) } \rightarrow \\
\text { Purchasing Decision (Y2) }\end{array}$ & 0,269 \\
\hline $\begin{array}{l}\text { Discount (X2) } \rightarrow \text { Purchasing } \\
\text { Decision (Y2) }\end{array}$ & 0,247 \\
\hline $\begin{array}{l}\text { Perceived Usefulness (X3) } \rightarrow \\
\text { Purchasing Decision (Y2) }\end{array}$ & 0,058 \\
\hline
\end{tabular}

\section{Table 1. Direct Influence}

\begin{tabular}{|l|l|}
\hline \multicolumn{2}{|l|}{ Indirect Influence } \\
\hline Inter-Variable Influence & $\begin{array}{l}\text { Path } \\
\text { Coefficient }\end{array}$ \\
\hline $\begin{array}{l}\text { Perceived Ease of Use (X1) } \rightarrow \\
\text { Intention to Use Grab } \\
\text { aplication (Y1) } \rightarrow \text { Purchasing } \\
\text { Decision (Y2) }\end{array}$ & 0,095 \\
\hline $\begin{array}{l}\text { Discount (X2) } \rightarrow \text { Intention to } \\
\text { Use Grab aplication (Y1) } \rightarrow \\
\text { Purchasing Decision (Y2) }\end{array}$ & 0,210 \\
\hline $\begin{array}{l}\text { Perceived Usefulness (X3) } \rightarrow \\
\text { Intention to Use Grab } \\
\text { aplication (Y1) } \rightarrow \text { Purchasing } \\
\text { Decision (Y2) }\end{array}$ & 0,077 \\
\hline
\end{tabular}

\section{Table 2. Indirect Influence}

\section{The Influence of Perceived Ease of Use on Intention Use Grab Application}

Based on path analysis, it is known that perceived ease of use has a significant effect on intention to use Grab application. From the results, it can be seen that the more perceived 
ease of use of the application, the higher the intention to use the Grab application. Bisides, it can be known that the perceived ease of use of Grab application that is felt by undergraduate students in business administration study programs for 2017 and 2018 Faculty of Administrative Sciences, Universitas Brawijaya is good now. This good consumer's perception includes all Grab services in transportation, courier and online shopping services.

The result of this study is in accordance with the theory stated by Jogyanto (2007: 112) that perceived ease of use has an influence on buying interest. Technology users will have an interest in using technology if they feel technology is easy to use. The results of this study are also supported by previous research conducted by Al-Sharaf (2017), Ermawati and Delima (2016), Hamid (2016) showing that there is an influence of perceived ease of use on intention to use technology. It can be concluded that $\mathrm{H} 1$ is accepted

\section{The Influence of Discount on Intention to Use Grab Application}

Based on the path analysis, it is known that the discount has a significant effect on the intention to use Grab application. From the results, it can be seen that the more discount given by Grab, the higher the intention of respondent to use the Grab application. Bisides, it can be known that the discount felt by undergraduate students in business administration study programs for 2017 and 2018, Faculty of Administrative Sciences, Universitas Brawijaya, Malang is currently good at encouraging consumer intention to use the Grab application. This good discount includes all Grab services in transportation, courier and online shopping services. The type of discount that is most popular with respondents is a discount in the form of a promo code.

The results of the study are also in line with the theory state by Kotler and Keller (2007: 103) say that giving discounts will encourage consumer intentions for faster payments, bulk purchases, and off-season purchases. Research conducted by Santini (2015), Mir, (2012), revealed that promotion through giving discounts has a positive influence on consumer intentions. It can be concluded that $\mathrm{H} 2$ is accepted

\section{The Influence of Perceived Usefulness on Intention to Use Grab Application}

Based on path analysis, it is known that perceived usefulness has a significant effect on the intention to use Grab application. From the results, it can be seen that the more perceived of usefulness of the Grab application, the higher consumer's intention to use 
the Grab application. Bisides, it can be known that The perceived of usefulness of Grab application that's felt by undergraduate students in business administration study programs for 2017 and 2018, Faculty of Administrative Sciences, Universitas Brawijaya, Malang good. This good perceived of usefulness includes all Grab services in the form of transportation, courier and online shopping services.

The results of this study is in line with the theory put forward by Jogyanto (2007: 112) that perceived usefulness has an influence on interest in behavior (buying). Technology users will have an interest in using technology if they feel useful technology. This study also supports previous research conducted by Al-Sharafi (2017), Ermawati and Delima (2016), Hamid (2016) revealing that there is an influence of perceived usefulness on intention to use technology. It can be concluded that $\mathrm{H} 3$ is accepted

\section{The Influence of Intention to Use Grab Applications on Purchasing Decisions of Grab Services}

Based on the path analysis, it is known that the intention to use the application has a significant effect on purchasing decisions. From the results, it can be seen that the more perceived ease of use of Grab application, the higher consumer's purchasing decisions of Grab services. Bisides, it can be known that the intention to use the Grab application felt by the undergraduate students in business administration study programs for 2017 and 2018 Faculty of Administrative Sciences, Universitas Brawijaya is good now. The intention to use Grab application to buy Grab services is important because by having a Grab application, consumers will more often purchase all Grab services in transportation, courier and online shopping services.

The results of this study is supported by the theory conveyed by Kotler (2012: 2007) that in the evaluation phase of the purchasing decision process, consumers make preferences or interests in brands, consumers may also have an interest in buying the most preferred products. Then Jogyanto (2007: 115) says that purchase intention is a good predictor of the use of technology by the users of the system. This research is also supported by previous research conducted by David, et al. (1989), Venkatesh and Davis (2000) which show that buying interest influences the use of technology. It can be concluded that $\mathrm{H} 4$ is accepted 


\section{The Influence of Perceived Ease of Use on Purchasing Decisions}

Based on path analysis, it is known that perceived ease of use has a significant effect on purchasing decisions. From the results, it can be seen that the more perceived ease of use of the application, the higher consumer's purchasing decisions on Grab services. Bisides, it can be known that perceived ease of use is felt by undergraduate students in business administration study programs for 2017 and 2018 Faculty of Administrative Sciences, Universitas Brawijaya is good. The perceived ease of students includes all Grab services in the form of transportation, courier and online shopping services.

The results of the study are in accordance with the theory stated by Pavlou (2002) that perceived ease of use is a factor that influences a person to use or buy technology. In addition, this study is also supported by research conducted by Fatuh and Widyastuti (2017), Johar (2011), Shen and Chiou (2010) which reveal that there is an influence of perceived ease of use on purchasing decisions or the use of technology. It can be concluded that $\mathrm{H} 5$ is accepted

\section{The Influence of Perceived Usefulness on Purchasing Decisions}

Based on path analysis, it is known that perceived usefulness has not significant effect on purchasing decisions. This happens because in the purchase decision of Grab services in the kind of transportation, courier, and online shopping services through perceived usefulness, it is not a priority for students if it is not supported by low prices through giving discounts and ease in operating applications. Students still have other alternatives such as using conventional transportation or shopping directly. This is what causes students to cancel purchasing decisions and just. Based on the analysis, the perceived of usefulness does not always influence consumers purchasing decisions.

The results of this study is not supported by the theory expressed by Pavlou (2002) that perceived usefulness is a factor that influences someone to use or buy technology. This study also is not support the previous research conducted by Ermawati and Delima (2016), (Al-Sharafi, 2017), (Johar, 2011) revealing that there is a perceived usefulness influence on the decision to use technology. It can be concluded that H6 is rejected

\section{The Influence of Discount on Purchasing Decisions}

Based on the path analysis, it is known that the discount has a significant effect on purchasing decisions. . From the results, it can be seen that the more discount which given 
by Grab, the higher consumers purchasing decisions on Grab services. Bisides, it can be known that the Grab discount that felt by undergraduate students in business administration study programs for 2017 and 2018 Faculty of Administrative Sciences, Universitas Brawijaya, Malang is good now. Discount, which is felt by good students, covers all Grab services in the form of transportation, courier and online shopping services. The type of discount that is most popular with respondents is a discount in the form of a promo code. This is because discounts are given through promo codes more often and the value is relatively more than other types of Grab discounts.

The results of this study is support the theory that stated by Kotler and Keller (2007: 103) giving discounts will encourage consumer intentions for faster payments, bulk purchases, and off-season purchases. Previous research conducted by Faryabi et al (2012) and Fatuh \& Widyastuti (2017) also revealed that giving discounts has a positive influence on purchasing decisions. It can be concluded that $\mathrm{H} 7$ is accepted

\section{DISCUSSION}

From the results of the description analysis it conclude that the majority of respondents were female, 18 years old and began using Grab services since 2017. Before deciding to buy Grab services the majority of respondents sought information about Grab's services. The most commonly used Grab services by respondents are GrabBike, GrabCar, and GrabFood. All respondents in this study have already received a Grab discount. The most commonly used discount is the Grab discount in the form of a promo code. From the results of the variables description analysis, the respondent's answer that the variables Perceived Ease of Use, Discount, Perceived Usefulness, Intention to Use the Application, and Purchase Decision is good or high.

Based on this research, it can be concluded that perceived ease of use has a significant influence on intention to use Grab application. Discount has a significant influence on intention to use the Grab application. Perceived usefulness has a significant influence on intention to use Grab application. Perceived ease of use, discount, and perceived usefulness have an influence on purchasing decisions through the intention to use Grab application.

Perceived ease of use has a positive and significant influence on purchasing decision. Discount has a positive and significant influence on purchasing decision. Perceived usefulness has not significant influence on purchasing decision. 


\section{Research Limitations}

The findings reported here are show that the complex relationship among Perceived Ease of Use, Discount, Perceived of Usefulness on Intention to use Grab application and it's impact on purchase decision. Future research efforts should attempt to develop further insight into this relationship. :

1. Those who use the grab application come from all types of ages, while this study only conducted research on students aged 17-20 years

2. this study only examines students, further research is expected to be able to examine other professions such as lecturers, employees of private companies or civil servants

3. This research only focuses on bachelor degree of Business Administration study program 2017 and 2018 Faculty of Administrative Sciences, Universitas Brawijaya, Malang. For further research, it is expected to conduct research on another study programs, faculties, and universities.

4. This study only focuses on the variables perceived ease of use, discount, perceived usefulness, intention to use the application and the purchase decision of Grab services. Future studies are expected to add variables such as word of mouth, perceived of risks that have not been included in this study. 


\section{REFERENCES}

Al-Sharafi, M. A. (2017). The Effect of Perceived Ease of Use and Usefulness on Customers Intention to Use Online Banking Services : The Mediating Role of Perceived Trust. International Journal Of Innovative Computing, 7(1), 9-14.

Davis, F.D. 1989. Perceived Usefulness, Perceived Ease of Use dan Acceptance ofInformation System Technology.MIS Quartery, Vol. 13, No. 3, h.319339.

Ermawati, N dan Delima, Z. M. (2016). Pengaruh Persepsi Kemudahan Penggunaan,, Persepsi Kegunaan, Dan Pengalaman Terhadap Minat Wajib Pajak Menggunakan Sistem E-Filing. Jurnal Akuntansi Indonesia, 5(2), 163174.

Faryabi, M. e. (2012). The Effect of Price Discounts and Store Image on Consumer's Purchase Intention in Online Shopping Context Case Study: Nokia and HTC. Journal of Business Studies Quarterly, 4(1), 197-205

Fatuh, M., dan Widyastuti. (2017). Pengaruh Promosi Penjualan, Perceived Ease of Use dan Perceived Usefulness terhadap Keputusan Menggunakan Transportasi Online (Studi Pada Pengguna Uber di Surabaya Pusat). Jurnal Ilmu Manajemen, 5(4), 1-9.

Hamid, A. A. (2016). The Effects Of Perceived Usefulness And Perceived Ease of Use On Continuance Intention To Use E-Government. Procedia Economics and Finance, 35, 645-649.

Hsieh, J.-Y., dan Liao, P.-W. (2011). Antecedents And Moderator Of Online Shopping Behaviour in Undergraduate Students. SOCIAL BEHAVIOR AND PERSONALITY, 39(9), 1271-1280.

Jogiyanto, 2007. Sistem Informasi Keperilakuan. Edisi Revisi. Yogyakarta: Andi Offset

Johar, M. G. (2011). The Role Of Technology Acceptance Model In Explaining Effect On E-Commerce Application Application System. International Journal of Managing Information Technology (IJMIT), 3(3), 1-14.

Kotler dan Keller.2007. Manajemen Pemasaran Edisi 12Jilid 1. Jakarta: IndeksPrentice Hall.

Kotler dan Keller. (2012). Manajemen Pemasaran. Edisi 12. Jakarta: Erlangga 
Mir, I. A. (2012). Impact of Different Levels of Instant Price Discounts On Consumer Perceptions and Purchase Intentions. АКТУАЛЬНІ ПРОБЛЕМИ ЕКОНОМІКИ, 5, 409-416.

Pavlou, Paul A., dan D. Gefen. 2002. Building Effective Online Marketplaces withInstitution-based Trust. Proceedings of Twenty-Third InternationalConference on Information Systems. pp. 667-675.

Santini, F. d. (2015). An analysis of the influence of discount sales promotion in consumer buying intent and the moderating effects of attractiveness. R.Adm., São Paulo, 50(4), 416-431.

Shen, C.-C., dan Chou, J.-S. (2010). The impact of Perceived Ease of Use on Internet service adoption : The moderating effects of temporal distance and perceived risk. Computers In Human Behaviour, 26, 42-50.

Tjiptono, Fandy, 2008, Strategi Pemasaran, Edisi 3, ANDI: Yogyakarta Venkatesh, V dan F.D. Davis. 2000. “ A Theoritical Extension of The Technology Acceptance Model $=$ Four Longitudinal Fields Studies "Management Science Vol. 46, No. 2, Februari, h.186-204 